\title{
Determinants of Export Propensity and Intensity of Manufacturing Firms in Cameroon: An Empirical Assessment
}

\author{
Dobdinga C. Fonchamnyo ${ }^{1}$ \\ ${ }^{1}$ Department of Economics \& Management, University of Buea, P.O. Box 63, Buea, S.W. Region, Cameroon
}

Received: May 12, 2014

doi:10.11114/aef.v1i2.413
Accepted: May 29, 2014

URL: http://dx.doi.org/10.11114/aef.v1i2.413

Available online: August 12, 2014

\begin{abstract}
Many Developing Countries in the process of economic transition have engaged themselves with outward-looking export oriented policies, aimed at making their manufacturing sector very competitive. In this regard, this study aimed at examining the factors that can influence both the level of exports and the likelihood to export of manufacturing firms. The data for the study was obtained from the World Bank Investment Climate Survey (ICS). The findings from this survey showed that the turnaround time for cargo clearance at the port is faster for exporters than for importers (15.1 to 23.9 days), while transportation and energy supply were cited by more than half of the firms as key obstacles to production. The key empirical findings on the one hand showed that human capital; years of experience, turnover, and modernization have positive effect on both the likelihood to export and on the export intensity. On the other hand, insecurity and power outage have a detrimental effect on export performance. The results also pointed to the fact that many of the firms were labour intensive firms, taking advantage of the abundant cheap labour in the country. These results put together, provide insights into some policies needed to promote the performance of export manufacturing firms in Cameroon, among which include an improvement in human capital, turnover, electricity supply, security and use of technological modernized equipment.
\end{abstract}

Keywords: Manufacturing firms, Cameroon, Export, Tobit

JEL Classification Number: L2, L6

\section{Introduction}

Many countries in the process of economic transition have adopted outward-looking export oriented policies. These policies have concentrated and focused its attention on encouraging domestic transformation of raw materials, with the aim to reduce foreign dependence, increase export competitiveness and improve economic stability and growth. A look at the manufacturing sector in Cameroon shows that the sector though still recovering from a decade of economic crisis has witnessed a gradual improvement. Statistics from the African Development Indicators show that the manufacturing sector has grown over time as witnessed by the positive growth rate of the value added in the manufacturing sector. Precisely, the value added in manufacturing (\% of GDP) picked up from an average of less than $14 \%$ before 1992 to over 20\% between 1992 and 2000. Though a decline was witnessed between 2005 and 2010, the average has remained above $15 \%$. The increasing contribution of manufacturing to GDP has been accompanied by an increasing proportion of manufactures in total exports. According to statistics from the African Development Indicators (2013), this proportion has increased from an average of less than $8 \%$ between 1990 and 2006 to over 15\% since 2007.

The growing importance of the manufacturing sector as illustrated above supports the idea that it is important to promote firms that carry out exportation as a means of achieving sustainable growth and development. To achieve this, the movement of firms in and out of the industry and the procedure involved in exportation should be closely monitored. By so doing, firms' activities related to exportation can be enhanced, by bringing to light the variables that can motivate both the likelihood of exportation and the quantity that a firm finally sells to the foreign market (that is, export level or intensity). Thus, we believe there is a need for a careful examination of the factors that influence both the propensity and level of export, with emphasis on the factors from firm's own characteristics.

The literature on factors influencing the export behaviour of firms is quite exhaustive and can be divided in two strands. On the one hand, a handful of the literature focused on the export propensity of manufacturing firms; while at the same time a couple of studies have considered factors influencing the level of exports, that is, the export intensity. Though the decision on whether to export or not seems to move alongside the decision on what quantity to export; current studies have shown that the impact of the various variables on these decisions are not homogenous. This argument is in support of the 
findings by Calvo (undated), Rojec et al. (2001), Şentürk and Erdem (2008), and Helpman et al. (2008). Moreover, the results from previous studies are not homogenous. Most studies (Okado, 2013; Shiferaw, 2007 and Yoshino, 2007) showed that factors such as size, the longevity of the firm in production, power outage, productivity and innovative activities are very important factors influencing the export intensity of firms. New vintage capital and the number of permanent workers are found to have a significant positive effect on export intensity (Yoshino, 2007). As concerns age a non-linear relationship is found by Wagner (2005), while Okado (2013) and Yoshino (2007) find a negative but statistically insignificant effect between age and export level. In terms of factor intensity motivators, Rojec et al. (2001) found out that capital intensity did not significantly influence the likelihood to export; while skill intensity had the desired positive and statistically significant effect. Other results showed that the level of experience in exportation is also a key determinant of export propensity (Parish and Freeman, 2011).

The determinants of export propensity of firms as reviewed above seem exhaustive. However, few studies have focused on this in developing countries especially those in Sub Saharan Africa due to inadequate or unavailability of data. Thus, in this study focus is placed on answering the following questions;

- What are the environmental and firm specific factors influencing the export intensity of manufacturing firms in Cameroon?

- To what extent are the environmental and firm specific factors accountable for the differences in the likelihood or propensity of manufacturing firms to export in Cameroon?

The study therefore sets out to achieve two key specific objectives;

- To identify the environmental and firm specific factors that influence the export intensity of manufacturers in Cameroon,

- To determine the environmental and firm specific factors that account for the differences in the likelihood to export by Cameroon's manufacturing firms.

The following hypothesis is therefore tested in this study;

- Environmental and firm specific factors do not influence the intensity and propensity to export by manufacturing firms in Cameroon.

In order to achieve the above, the rest of this paper has been partitioned in to the following components; the literature review which reviews existing work; data presentation and methodology, while the two last sections present the findings, policy implications and conclusion.

\section{Review of Related Literature}

A handful of studies have examined either the factors influencing the likelihood to export or the level of export or both. Many of the studies examined factors related to the firm's own characteristics and the socio-economic environment. Among the firm's characteristics identified are productivity, age, size, turnover, human capital, factor intensity and vintage capital. In terms of productivity, a mixture of empirical results has been found in the literature. Liu et al. (1999) in their study on the intensity of export revealed that productivity did not play a statistical significant role in influencing the quantity of goods exported. This result is also established by Castellani (2002) when studying the factors influencing the level of export by manufacturing firms in Italy.

Other researchers have found mixed results on the effect of productivity for different industries in the same country; for instance, in the study of firms from Spain, Farinas and Martin-Marcos (2007) found out that the effect of productivity was heterogeneous for export oriented and domestic firms. A set of studies meanwhile have shown empirically that labour productivity has a positive and statistical significant effect on the level and likelihood to export. For instance, in a study by Iyer (2010) on the level of export of New Zealand Agriculture and Forestry industry, it was shown that the productivity of firms influence the quantity exported by firms. This result is also supported by Alvarez (2002) in the study of Chilean firms and by Arnold and Hussinger (2005) in their study of the role of productivity on the level of exports in the manufacturing sector in Germany.

In terms of firm size, the results have not been as contradicting as for productivity. The results generally showed that as the firm size increases, both the level and probability to export will increase (Wagner, 2005 and Pope, 2004). Other studies have also indicated that motivators such as age, human capital, factor intensity, vintage capital (Beamish et al., 1993; Majocchi et al., 2005; Iyer, 2010; Yoshino, 2007 and Okado, 2013), are very instrumental when it comes to the decision and quantity to be exported. These studies all found a positive effect of these variables on the quantity of goods exported and or on the propensity to export. Other variables found to be detrimental to export performance include power outage and customs delay (Yoshino, 2007); crime and theft (Hiep and Nishijima, 2009)

From the literature review above, it is evident that the majority of the studies were conducted in the Developed Countries or Developing Countries out of Sub Saharan Africa. This therefore gives more impetus for a study of this magnitude in a developing country, located in Sub Saharan Africa like Cameroon, which has recognized the role of manufacturing firms 
and have over the years put policies to foster exportation. Based on the literature, the current paper will include variables in the models of export propensity and intensity that will capture factor intensity, firm specific characteristics and business environmental factors.

\section{Estimation Methodology and Data}

For the econometric analysis, we have employed two empirical models that will examine the factors influencing the export performance of manufacturing firms in Cameroon. The export behavior will be reflected by two decisions, viz; the probability of exporting (export propensity) and the proportion of output exported (i.e. export intensity). The econometric analysis is therefore framed to show that the two decisions can potentially be dependent. The specified models evade selection prejudices which can occur if focus is placed on only the probability of exporting or on the percentage to export. Thus, the methodology adopted can give some credibility to the results obtained in this study.

The export decision is expressed as follows:

$$
\begin{aligned}
& \text { EXP }_{i}=\alpha+\beta_{1} \text { Size }_{i}+\beta_{2} \text { Wage }_{i}+\beta_{3} \text { Hum }_{i}+\beta_{4} \text { Turn }_{i}+\beta_{5} \text { Age }_{i}+\beta_{6} \text { YExp }_{i} \\
& +\beta_{7} \text { Power }_{i}+\beta_{8} \text { Capi }_{i}+\beta_{9} \text { Vin }_{i}+\beta_{10} \text { In }_{\text {sec }}+\varepsilon_{i}
\end{aligned}
$$

Where $\operatorname{EXP}\left\{\begin{array}{l}=1 \text { if firm exports } \\ 0 \text { otherwise }\end{array}\right.$

While the export propensity equation is expressed as follows:

$$
\begin{aligned}
& E P_{i}=\alpha+\beta_{1} \text { Size }_{i}+\beta_{2} \text { Wage }_{i}+\beta_{3} \text { Hum }_{i}+\beta_{4} \text { Turn }_{i}+\beta_{5} \text { Age }_{i}+\beta_{6} \text { YExp }_{i} \\
& +\beta_{7} \text { Power }_{i}+\beta_{8} \text { Capi }_{i}+\beta_{9} \text { Vin }_{i}+\beta_{10} \text { In }_{\text {sec }}+v_{i}
\end{aligned}
$$

Where the error terms ( $\varepsilon_{i}$ and $v_{i}$ ) are normally distributed with mean zero and variance one and the subscripts $i$ refer to the firms.

The logit estimation technique is used to estimate equation (1), while equation (2) is estimated with the Tobit estimation technique, following Tobin (1958). The Tobit estimation model with a lower limit of "0" is specified as follows:

$$
Y_{i}^{*}=\beta^{\prime} X_{i}+\mu_{i}=\left\{\begin{array}{l}
Y_{i}^{*} \text { if } Y_{i}^{*}>0 \\
1 \text { if } Y_{i}^{*} \leq 0
\end{array}\right.
$$

Where $Y_{i}^{*}$ is the latent dependent variable and $Y_{i}$ is the observed counterpart, $X_{i}$ represents the independent variables as specified in equation (2) above and explained in Table 1, below.

The data for this study are secondary and were obtained from the firm-level World Bank Investment Climate Survey (ICS) data for manufacturing sector. This data are collected to assess the investment climate in the different countries. It is aimed at providing the background for sound policy formulation that can assist to foster a more conducive environment for investors and would be investors. The firms are surveyed using questions that have been designed to identify firm specific characteristics and factors that can promote or inhibit their activities. To facilitate the selection of firms in the sample, stratification of the firms is carried out to consider aspects such as the location, the sector of operation and the size of the firm.

For this study, the variables included in the estimation equations were selected from the survey depending on the response rate to the question concerned. Due to the high rate of non-response on some key variables that we will have wished to include in the regression equation, but cannot, the variables used in this study were therefore based on the fact that their rate of response were high. A detailed definition of the variables is given in Table 1 below;

Table 1. Definition of variables used in the estimation

\begin{tabular}{ll}
\hline Variable & Description \\
\hline$E X P$ & The likelihood to export, it takes the value of 1 if the manufacturing firm takes part in \\
exportation and 0 if it does not export \\
The proportion of exports in total sales of firm $i$ \\
Measured using the number of permanent workers in the firm. The higher the number of \\
permanent workers, the higher the economies of scales and hence an increase in export \\
intensity and likelihood \\
Average labour cost. The higher the cost of labour the less likely firms will employ \\
labour to increase production. Hence, a negative coefficient is expected
\end{tabular}




\section{Hum}

Turn

Age

YExp

Power

Capi (Capital Intensity)

Vin (New Vintage Capital)

Insec (Insecurity)
Refers to human capital and is proxy by level of education. It will have a positive influence on production, which will also influence the propensity and intensity of export positively

Firm's turnover, it is expected to have a positive sign

Number of years of operation, that is, 2013 minus year of establishment

Years of experience working in the sector, expected to have a positive influence on the propensity and intensity to export

Number of times electricity failed in a month

Percentage of capital stock to the total cost of labor

$\%$ of machinery 10 years old or less in total capital stock

Losses due to theft, robbery, vandalism or arson experienced in last fiscal year. This will discourage investment and consequently impact the likelihood and intensity to export negatively

As observed from the variables in the table above, the information in the survey collected by the World Bank is quite broad in perspective and capture aspects dealing with output, capital, employment, problems/constraint faced by firms, turnover, exports, age, taxation, and a host of others. From the survey, it is evident that few firms in Sub Saharan African do engage in the exportation of the final goods produced, thus it is necessary to examine the factors that motivate the firms to export so as to be able to understand why many forms in this region do not engage in exportation. Statistics from the survey shows that in Cameroon, only 54 firms actually exported their product out of a total of 363 firms sampled (i.e. the export participation rate is just $14.9 \%$ ), while the mean of exports as a percentage of total output sold of exporting firms to all international market is 37.907 percent. Among the 363 firms survey by the World Bank, 116 firms indicated that they were of the manufacturing category. It is important to mention here that the ICS data showed that of the 116 manufacturing firms only 34 actually participate in exporting their products.

The ICS data also cover aspects about the effectiveness of the port and custom department. Information from the World Bank survey shows that it takes about 15.2 days on average to complete exportation requirements, while it takes approximately 23.8 days to finalize customs' requirement for imported containers. Thus, the clearance time for goods is slower for importation than exportation (23.9 to 15.1 days). Other wide ranging variables relating to doing business covered by the survey include aspects dealing with environmental conditions surrounding the investors. In this light, issues of infrastructural efficiency such as electricity supply, water connection, and transportation are also included in the survey.

The responses provided by the 116 firms studied showed mark differences in relation to their perception on the accessibility and efficiency of the structures put at their disposal by the country as represented in Table 2, below.

Table 2. Descriptive statistics of key environmental factors

\begin{tabular}{lccc}
\hline Variable & Average & Minimum & Maximum \\
\hline Number of days to connect electricity & 17.2 & 2 & 60 \\
Frequency of power outage per month & 12.7 & 2 & 50 \\
Number of days to connect water & 14.6 & 1 & 60 \\
Frequency of water cuts per month & 9.6 & 1 & 60 \\
Number of days to get telephone line connected & 33.3 & 1 & 180 \\
\hline
\end{tabular}

Table 2 provides the averages of domestic infrastructure service quality items in relation to the mean number of days it can take to establish a fixed telephone line and to get electricity connected. The table also shows information on the frequency of interruptions in supply of key utilities like water and electricity witnessed by the firms in a given year.

It is evident from the table above that service qualities are not the best, as most of the service providers take more than 10 days on average to provide the service. In terms of frequency of failures, the average per month is also worrisome (for electricity it is 12.7 times on average with a maximum of 50, while for water supply it is 9.6 times on average with a maximum of 60), especially that these are basic facilities for effective production and eventual exportation/sales. The transportation quality is also highlighted as an obstacle in the survey (68 manufacturing firms considered this to either be a minor or major obstacle, while 48 do not consider it as an obstacle). Surprisingly, none of the manufacturing firms indicated that they used high broad band internet for their sales or purchase activities, indicative of the low level of usage of modern technology in their daily activities.

\section{Presentation and Discussion of Results}

The results of the export decision estimation are presented in column 1 of Table 3 below. Based on the results, the size, average wage, human capital, turnover, age and experience and vintage capital all have a positive influence on the 
decision to export.

Among these variables average wage and experience in the exportation sector are statistically insignificant, suggesting that they may not play an important role in the manufacturing firms' decision to export. The significance of the turnover and age variables suggests that if a firm has stayed in production for a long time and has grown large enough over time, it probability of exporting will increase. These results tie with the results derived from the empirical analyses by Robert and Tybout (1997) and Barrios et al. (2003), when studying the likelihood of exportation by firms in Columbia and Spain, respectively. The average wage coefficient though insignificant is consistent with the findings of Barrios et al. (2003); and Bernard and Jensen (2004) who considered production for exportation to be relatively skilled-intensive due to high labour cost.

However, in Cameroon, the insignificant effect can rather be attributed to the high quantity of low cost labour input, given that the country is blessed with abundant low cost skilled and unskilled labour.

Table 3. Estimation results

\begin{tabular}{|c|c|c|}
\hline \multirow{2}{*}{ Variable } & $\begin{array}{c}\text { Logit model } \\
\text { Propensity to export }\end{array}$ & $\begin{array}{c}\text { Tobit model } \\
\text { Export intensity }\end{array}$ \\
\hline & $\begin{array}{c}\text { Coefficient } \\
\text { (standard error) }\end{array}$ & $\begin{array}{c}\text { Coefficient } \\
\text { (standard error) }\end{array}$ \\
\hline Size & $\begin{array}{l}0.0086^{*} \\
(0.0051) \\
\end{array}$ & $\begin{array}{c}0.0002 * * * \\
(0.00004)\end{array}$ \\
\hline Wage & $\begin{array}{c}0.0648 \\
(0.1376) \\
\end{array}$ & $\begin{array}{c}0.0154 \\
(0.0151) \\
\end{array}$ \\
\hline Human capital & $\begin{array}{c}0.6596 * * \\
(0.3098)\end{array}$ & $\begin{array}{c}0.04062^{*} \\
(0.0240)\end{array}$ \\
\hline Turnover & $\begin{array}{c}0.9713 * * * \\
(0.3693) \\
\end{array}$ & $\begin{array}{c}0.0346 * * * \\
(0.0106) \\
\end{array}$ \\
\hline Age of firm & $\begin{array}{c}0.0355 * * \\
(0.0175)\end{array}$ & $\begin{array}{l}.0036^{*} \\
0.0019\end{array}$ \\
\hline Experience & $\begin{array}{c}0.0252 \\
(0.02707)\end{array}$ & $\begin{array}{c}0.0002 * * \\
0.0001\end{array}$ \\
\hline Number of Power outage & $\begin{array}{l}-0.0046 \\
(0.0170)\end{array}$ & $\begin{array}{c}-0.0049 * * \\
(0.0022)\end{array}$ \\
\hline Capital Intensity & $\begin{array}{l}-0.1419^{*} \\
(0.0879) \\
\end{array}$ & $\begin{array}{c}-0.0186 * * * \\
(0.0072) \\
\end{array}$ \\
\hline New Vintage Capital & $\begin{array}{l}0.0140 * * \\
(0.0070) \\
\end{array}$ & $\begin{array}{l}0.0080 \\
0.0057 \\
\end{array}$ \\
\hline Insecurity & $\begin{array}{l}-0.2022 \\
(0.7739)\end{array}$ & $\begin{array}{c}-0.2017 * * * \\
(0.1184)\end{array}$ \\
\hline Sigma & & $\begin{array}{c}0.2157 \\
(0.0328)\end{array}$ \\
\hline Pseudo $\mathrm{R}^{2}$ & 0.6561 & 0.8917 \\
\hline Number of observations & $\begin{array}{l}0 \text { left-censored observa } \\
79 \text { uncensored observa } \\
30 \text { right-censored obse }\end{array}$ & $\begin{array}{l}\text { ls } \\
\text { s } \\
\text { ions at export } 1>=1\end{array}$ \\
\hline
\end{tabular}

*** Significant at $1 \%, * *$ significant at $5 \%$ and * significant at $10 \%$

The coefficient for new vintage capital, a technological factor is positive. This is consistent with Yoshino (2007) assertion that newly acquired investment produces a better and more advanced output than the old stock of capital; thus enhancing the likelihood to export and the quantity of goods exported.

Power outage and insecurity; although statistically insignificant have a negative effect on the firm's likelihood to engage in exportation. Capital intensity has a negative and statistically significant effect on the likelihood to export. One reason for the negative coefficient of the capital intensity variable may be ascribed to the fact that most of the manufacturing firms in the country are labour intensive firms who take advantage of the cheap labour available in the country. This result is consistent with the statistical insignificant effect result obtained for the wage coefficient.

The results of the export intensity estimation are presented in column 2 of Table 3 . The quantitative results in terms of the signs of the coefficient are quite consistent with the results of the decision to export. The main differences exist in the magnitude and the level of significance. For instance, years of experience is positive and significant in the export 
propensity regression, where as it is positive and statistically insignificant in the export intensity equation. A similar result is observed for power outage and insecurity which are statistically significant in the export intensity equation, but not statistically significant for the equation of export propensity.

Quantitatively, the results from column one showed that an increase in firm's size measured by the number of permanent employment will result to an increase in the likelihood to export, which will in turn increase the level of export by manufacturing firms in Cameroon. The results precisely showed that if the number of permanent employees were to increase by one, the log odd of exporting will increase by 0.0086 . That is, the odd of exporting is 73.68 percent higher if the number of permanent employees were increased by one unit. Similarly, an increase in human capital, turnover and age of the firm will result to an increase in the likelihood of the manufacturing firms to export by 0.6596 , 0.9713 and 0.0355 , respectively. These results are consistent with those obtained by Yoshino (2007), Şentürk and Erdem (2008) and Okada (2023) using similar estimation techniques. The number of power outage, capital intensity and insecurity all exert a negative effect on the likelihood to export and consequently the quantity exported. The results actually showed that a unit increase in insecurity will result to a fall in the log odd of exporting by 20.22 percent, while an increase in the number of power outage will reduce the log odd to export by 0.46 percent. These results are consistent in sign with those obtained by Yoshino (2007) and Hiep and Nishijima (2009)

The results from the two equations put together showed that power outage and insecurity are very detrimental to manufacturing firms involved in the export sector, while turnover, experience, new technology and human capital are quite instrumental to these firms. The results also point to the fact that the manufacturing firms are quite labour intensive, taking advantage of the cheap and abundant labour in the country to increase production using more labour than capital.

\section{Policy Implications and Conclusion}

Many countries in the process of development use exports as a development strategy and a growth engine. For such policies to be successful in its export steered growth strategies, it is imperative that the country provides a level playing ground for the firms who strive to reach the international marketplaces. Hence, a full knowledge of the motivators of firms' productivity in this direction has wide-ranging repercussions. The current paper tries in this effort to examine the effect of the motivators (environmental and firm's structures) on the intensity and likelihood to export by manufacturing firms in Cameroon. This was achieved by employing a longitudinal data obtained from the Investment Climate Survey (ICS) data of the World Bank. The results on the one hand revealed that the likelihood to export is positively and significantly influenced by size, human capital, turnover and age, while capital intensity have a significant negative influence on the likelihood to export. On the other hand, the export intensity is positively influenced by firm size, human capital, turnover, age and experience. The results also revealed that insecurity, power outage and capital intensity play a negative and statistical significant role on the intensity to export by manufacturing firms in Cameroon.

The foregoing results revealed that the challenge facing policymakers (government and firms) therefore is to persistently improve on the capital and human resources, and on the abilities of the manufacturing firms to fully engage in exports, regardless of their industry. This effort has been recognized by the government as evident by policies put in place for the past couple of years, among which include a new investment code, restructuring the custom department to speed up container clearance, creation of a one stop shop to facilitate the setting up of businesses, privatization of the electricity and water supply corporations, among others. This notwithstanding, more still has to be done. In this regard, there is need to increase firms' export propensity and intensity by assisting firms to identify and develop their human resources, improving security, encouraging the use of new technology and replacing obsolete ones. In addition, the government still has to do much to improve on the electricity and water supply sectors, they still remain a perennial problem and hence efforts should be put in place to reduce the frequency of power outage and water cuts.

In this regards, firms can therefore be encouraged to import and make use of environmental user friendly generators for electricity supply and digging their boreholes for regular water supply. There is also need to speed the time taken to clear containers at the port - though Cameroon has witnessed an improvement in this sector, the average clearing time at the port still remains one of the highest in Sub Saharan Africa (for instance, Statistics from World Development Indicators indicates that it takes on average 15.1 days in Cameroon, 7.5 days in Nigeria, 7 in Benin, and 7.4 in Burkina Faso). There is also an urgent need to improve on security and theft, robbery and vandalism, since they continue to pose a serious threat to both foreign and home investors.

In conclusion, exports are set in the development strategies of many developing countries, as a means for improving firms' financial and competitive performance. In addition, countries adopting export-led-growth strategies considered it as an engine for growth. For this strategy to succeed, it is important for countries like, Cameroon and other developing nations to pave a smoother way for firms in their efforts to reach the international markets. This is quite possible when the environmental and firm specific factors that influence the firms' performance are identified. The findings thus showed a combination of factors that have varying level of influence on both the intensity and propensity to export by manufacturing firms. Among these factors; experience, human capital, cheap labour, turnover, insecurity, power outage and innovations are motivators that should be given special consideration by decision makers. 


\section{References}

Alvarez, R. (2007). Explaining Export Success: Firm Characteristics and Spillover Effects. World Development, 35(3). http://dx.doi.org/10.1016/j.worlddev.2006.11.002

Arnold, J. M., \& Hussinger, K. (2005). Export Behavior and Firm Productivity in German Manufacturing: A Firm-Level Analysis. Review of World Economics, 141(2). http://dx.doi.org/10.1007/s10290-005-0026-8

Barrios, S., Gorg, H., \& Strobl, E. (2003). Explaining Firms' Export Behaviour: R\&D and the Destination Market. Oxford Bulletin of Economics and Statistics, 65(4). http://dx.doi.org/10.1111/1468-0084.t01-1-00058

Beamish, P. R., Craig., \& McLellan, K. (1993). The Performance Characteristics of Canadian Versus U.K. Exporters in Small and Medium Sized Firms. Management International Review, 33.

Bernard, A., \& Jensen, J. B. (2004). Why Do Some Firms Export? The Review Economics and Statistics, 86(2). http://dx.doi.org/10.1162/003465304323031111

Castellani, D. (2002). Export Behavior and Productivity Growth: Evidence from Italian Manufacturing Firms. Review of World Economics, 138(4)

Calvo, José L. (undated). The Export Activity of Spanish Manufacturing Firms: Does Innovation Matter? Website: http://www.jyu.fi/ersa2003/cdrom/papers/129.pdf Accessed on May 5, 2014

Farinas, J. C., \& Martin-Marcos, A. (2007). Exporting and Economic Performance: Firm-Level Evidence of Spanish Manufacturing. The World Economy, 30(4). http://dx.doi.org/10.1111/j.1467-9701.2007.01007.x

Helpman, E., Melitz, M., \& Rubinstein, Y. (2008). Estimating Trade Flows: Trading Partners and Trading Volumes. Quarterly Journal of Economics, 123. http://dx.doi.org/10.1162/qjec.2008.123.2.441

Hiep, N., \&Nishijima S. (2009). Export Intensity and Impacts from Firm Characteristics, Domestic Competition and Domestic Constraints in Vietnam: A Micro-data Analysis. Paper presented at the RIEB Seminar on March 19, 2009. Website: http://www.apeaweb.org/confer/cruz09/papers/hiep-nishijima.pdf Accessed on May 5, 2014

Iyer, K. (2010). The Determinants of Firm-Level Export Intensity in New Zealand Agriculture and Forestry. Economic Analysis \& Policy, 40 (1)

Liu, J. T., Tsou M. W., \& Hammitt J. K. (1999). Export Activity and Productivity: Evidence from the Taiwan Electronics Industry. Review of World Economics, 135.

Majocchia, A., E., Bacchiocchib \& Mayrhoferc U. (2005). Firm Size, Business Experience and Export Intensity in SMEs: A Longitudinal Approach to Complex Relationships. International Business Review, 14 (6).

Okado, Abala D. (2013). Export Propensity and Intensity of Kenyan Manufacturing Firms: An Empirical Analysis. Journal of Emerging Issues in Economics, Finance and Banking (JEIEFB), 2(2).

Parish, C., \& Joanne F. (2011). Factors contributing to the export propensity of Australian seafood firms. Journal of New Business Ideas \& Trends, 9 (1)

Pope R.A. (2002). Why Small Firms Export: Another Look. Journal of Small Business Management, 40 (1). http://dx.doi.org/10.1111/1540-627X.00035

Roberts, M., \& Tybout J. (1997). The Decision to Export in Columbia: An Empirical Model of Entry with Sunk Costs, American Economic Review, 87 (4).

Rojec, Matija, Damijan J. P., \& Boris M. (2001). Export Propensity of Estonian and Slovenian Manufacturing Firms: Does Foreign Ownership Matter? Working Paper, 11.

Şentürk, İsmail, \& Cumhur E. (2008). Determinants of Export Propensity and Intensity of SMEs in Developing Countries: An Empirical Analysis of Turkish Firms. The Empirical Economics Letters, 7 (2).

Shiferaw, Admasu (2007). Firm Heterogeneity and Market Selection in Sub-Saharan Africa: Does it Spur Industrial Progress? Economic Development and Cultural Change, 55(2). http://dx.doi.org/10.1086/508713

Tobin, J. (1958). Estimation of Relationships for Limited Dependent Variables, Econometrica, 26 (1) http://dx.doi.org/10.2307/1907382

Wagner, J. (2005) Exports and Productivity: A survey of the evidence from firm level data. The World Economy. 30.

Yoshino, Y. (2007). Domestic Constraints, Firm Characteristics and Geographical Diversification of Firm-Level Manufacturing Exports in Africa. African Economic Conference, November 15-17, 2007, Addis Ababa.

(cc) $\mathrm{Br}$

This work is licensed under a Creative Commons Attribution 3.0 License. 